\title{
ANALISIS PENGARUH PEMILIHAN JENIS BEKISTING TERHADAP DURASI DAN BIAYA PELAKSANAAN PEKERJAAN STRUKTUR PROYEK X
}

\author{
Wilsen Hartanto Lim $^{1}$ dan Arianti Sutandi \\ ${ }^{1}$ Program Studi Sarjana Teknik Sipil, Universitas Tarumanagara, Jl. Letjen S. Parman No.1 Jakarta \\ wilsen.325160115@stu.untar.ac.id \\ ${ }^{2}$ Program Studi Sarjana Teknik Sipil, Universitas Tarumanagara, Jl. Letjen S. Parman No.1 Jakarta \\ ari.sutandi@gmail.com
}

Masuk: 13-01-2020, revisi 17-02-2020:,diterima untuk diterbitkan: 11-11-2021

\begin{abstract}
The planed duration of construction Project $X$ was 730 days with the upper structure targeted to be finished in July 2020. There was delay in the beginning of project implementation and the expected duration became 745 days, the upper structure completion date pushed back to October 2020. In order to keep in line with target, one of the alternatives was to change the formwork material from conventional to aluminium. By applying this change, there was a need to study the effects to the project duration, the upper structure finish date, and the additional cost. To calculate the project duration, and the labour coefficient of productivity using the motion and time study method, the completion time of aluminium formwork work is required. From the calculation, it can be concluded that it was more effective to apply an 8-zone of formwork division in every storey, which will result in 711 days of project duration and the upper structure finish date will be in August 2020. The costs for the aluminium formwork which consisted of materials and labour fees amounted to $R p$ 7,991,548,555 or higher by $R p$ 1,000,000,000 compared to conventional formwork.
\end{abstract}

Keywords: High-rise building, delay, motion and time study, labour coefficient, duration, costs.

\begin{abstract}
ABSTRAK
Target durasi pekerjaan konstruksi proyek X adalah 730 hari dengan target waktu selesai pekerjaan struktur atas pada bulan Juli 2020. Pada awal pelaksanaan proyek terjadi keterlambatan sehingga diperkirakan menghasilkan durasi proyek 745 hari dan waktu selesai pekerjaan struktur atas menjadi Oktober 2020. Untuk mengejar target proyek, salah satu alternatif yang dapat dilakukan adalah dengan mengganti jenis material bekisting dari konvensional menjadi aluminium. Sehingga dengan penggantian tersebut perlu dilakukan studi pengaruh penggantian jenis bekisting terhadap durasi proyek, waktu selesai pekerjaan struktur atas, dan biaya pekerjaan bekisting. Untuk menghitung durasi proyek, dan koefisien tenaga kerja yang dilakukan dengan metode motion and time study diperlukan waktu pekerjaan bekisting aluminium. Dari perhitungan durasi proyek diperoleh waktu yang lebih efektif adalah dengan pembagian 8 zona yang menghasilkan durasi proyek 711 hari dan waktu selesai pekerjaan struktur atas adalah Agustus 2020. Untuk biaya pekerjaan bekisting aluminium yang terdiri dari biaya material dan biaya upah tenaga kerja didapatkan total biaya adalah Rp 7,991,548,555 atau lebih besar sekitar Rp 1,000,000,000 dibandingkan dengan bekisting konvensional.
\end{abstract}

Kata kunci: Bangunan tinggi, keterlambatan, motion and time study, koefisien tenaga kerja, durasi, biaya.

\section{PENDAHULUAN}

Kegiatan konstruksi merupakan kegiatan yang tidak dapat berdiri sendiri, namun merupakan suatu rangkaian kegiatan yang saling memiliki keterkaitan antara kegiatannya. Dalam proses pelaksanaan konstruksi, diperlukan penjadwalan yang tepat untuk mengendalikan kegiatan proyek. Namun dengan adanya penjadwalan tidak dapat menjamin keterlambatan dapat terhindar dikarenakan adanya perbedaan antara rencana dan kenyataan yang terjadi di lapangan. Sehingga untuk mengatasi keterlambatan yang kerap terjadi dapat dilakukan percepatan durasi proyek dengan mengubah metode pelaksanaan konstruksi. Salah satu alternatif metode pelaksanaan konstruksi adalah pada pekerjaan bekisting berdasarkan jenis bekisting yang digunakan untuk struktur beton.

Bekisting merupakan komponen struktur sementara yang memikul beban-beban seperti komponen-komponennya, beban tukang, dan beton yang belum mengeras untuk merealisasikan struktur beton suatu bangunan agar sesuai 
dengan rencana. Menurut Wigbout (1992), jenis bekisting terdiri dari bekisting konvensional, bekisting setengah sistem, dan bekisting sistem.

Pada proyek X yang merupakan proyek bangunan tinggi terjadi keterlambatan waktu mulai pekerjaan relokasi stasiun existing karena masalah koordinasi antara pihak-pihak terkait. Sehingga menyebabkan target proyek yang terdiri dari: batasan durasi proyek 730 hari dan batas waktu selesai pekerjaan struktur atas pada bulan Juli 2020 tidak akan tercapai. Untuk mengejar target proyek perlu diupayakan percepatan pekerjaan proyek. Salah satu alternatif percepatan adalah dengan mengganti jenis material bekisting dari bekisting konvensional menjadi bekisting aluminium. Sehingga diperlukan studi untuk mengetahui pengaruh penggantian jenis bekisting terhadap durasi proyek dan biaya pekerjaan bekisting.

Identifikasi masalah pada proyek ini adalah:

1. Waktu mulai kegiatan kritis proyek mundur, sehingga jika proyek dilaksanakan sesuai dengan rencana awal diperkirakan waktu selesai proyek akan mundur.

2. Pengaruh perubahan pemakaian jenis bekisting konvensional menjadi bekisting sistem terhadap durasi proyek.

3. Pengaruh perubahan jenis bekisting yang akan digunakan terhadap anggaran biaya proyek.

4. Penggunaan bekisting aluminium belum umum dan masih jarang digunakan pada proyek konstruksi di Indonesia.

Berdasarkan latar belakang dan identifikasi masalah, rumusan dalam penelitian ini adalah sebagai berikut:

1. Berapa durasi total proyek $X$ dengan penggunaan bekisting aluminium?

2. Kapan waktu selesai pekerjaan struktur atas dengan penggunaan bekisting aluminium?

3. Berapa biaya yang dibutuhkanuntuk pekerjaan bekisting aluminium pada proyek $\mathrm{X}$ ?

Tujuan dari penelitian ini adalah untuk mengetahui:

1. Durasi total proyek X dengan penggunaan bekisting aluminium.

2. Waktu selesai pekerjaan struktur atas dengan penggunaan bekisting aluminium.

3. Biaya yang dibutuhkan untuk pekerjaan bekisting aluminium pada proyek X.

Batasan masalah dalam penelitian ini adalah:

1. Perhitungan durasi dan biaya upah tenaga kerja pekerjaan bekisting dihitung untuk proyek X.

2. Penggunaan alternatif jenis bekisting adalah bekisting aluminium.

3. Pengamatan untuk pekerjaan bekisting aluminium dilakukan di proyek Y.

\section{Manajemen Proyek}

Manajemen proyek merupakan pengaplikasian dari ilmu pengetahuan, kemampuan-kemampuan, dan teknik-teknik dalam pelaksanaan kegiatan proyek untuk tercapainya persyaratan proyek, (Project Management Institute, 2013) . Manajemen proyek dapat tercapai melalui proses manajemen yang terintegrasi dari kegiatan-kegiatannya seperti tahap memulai, tahap perencanaan, tahap pelaksanaanm tahap pengawasan, tahap pengendalian, dan tahap penutupan.

\section{Penjadwalan Proyek}

Penjadwalan proyek merupakan satu kegiatan dari manajemen proyek yang mengalokasikan sumber daya seperti material, uang, tenaga kerja, peralatan, metode kerja untuk kegiatan khusus, dan menghubungkan kegiatan satu dengan lainnya. Penjadwalan juga dikaitkan dengan perencanaan proses dalam melaksanakan suatu proyek dengan mengentukan metode-metode konstruksi yang akan digunakan, serta penetapan jasa atau keahlian yang akan digunakan dalam pelaksanaannya. Penjadwalan yang berhasil ialah penjadwalan pada suatu proyek dengan sumber daya yang dialokasikan dapat sesuai dengan waktu dan biaya yang telah direncanakan.

\section{Jaringan Kerja / Network Planning}

Pengalokasian sumber daya yang baik dalam kaittannya terhadap waktu pelaksanaan proyek dapat digunakan diagram jaringan kerja (Widiasanti \& Lenggogeni, 2013). Jaringan kerja yang dimaksud adalah jaringan sebagai gambaran kegiatan-kegiatan proyek dan kejadian-kejadian yang diperlukan untuk mencapai tujuan proyek. Kegiatan proyek dengan hubungan ketergantungan antara satu dengan lainnya disajikan dengan menggunakan tanda-tanda yang menjadi metode dari jaraingan kerja, salah satunya yaitu metode Activity On Node.

\section{Activity On Node}

Metode Activity On Node adalah metode dengan penulisan untuk kegiatan-kegiatannya didalam node yang umumnya berbentuk segi empat dan adanya anak panah yang hanya sebagai petunjuk hubungan antara kegiatankegiatan yang bersangkutan. Yang termasuk dalam metode AON adalah metode Precedence Diagram Method (PDM). Node berbentuk kotak dalam jaringan PDM menandai suatu kegiatan, sehingga perlu untuk 
mencantumkan identitas kegiatan dan kurun waktunya. Dalam ruangan node terdiri dari keterangan seperti: kurun waktu kegiatan, identitas kegiatan (nomor dan nama kegiatan), mulai dan selesainya kegiatan (ES, EF, LS, LF, a, b, c, d) (Soeharto 1999).
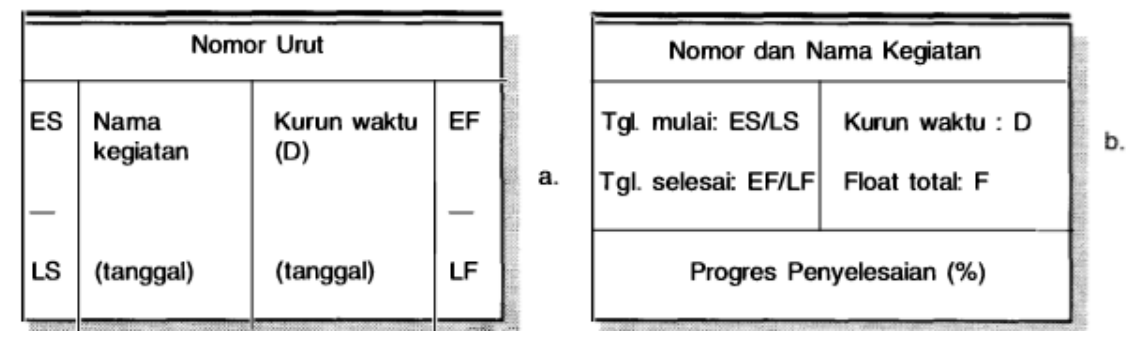

Gambar 1. Bentuk Diagram AON/PDM (Soeharto, 1999)

\section{Pengaturan Zona Proyek Konstruksi}

Pada perencanaan proyek konstruksi untuk bangunan tinggi, terdapat pengaturan untuk pembagian area-area pekerjaan yang disebut dengan zona. Pengaturan zona bertujuan untuk memudahkan sirkulasi pekerjaan dan pengadaan materialdan alat pada lapangan. Pengaturan zona-zona pekerjaan didasari oleh beberapa pertimbangan seperti:

1. Metode pekerjaan.

2. Jadwal pelaksanaan pekerjaan.

3. Ketersediaan sumber daya.

4. Ketersediaan lahan untuk mobilisasi material dan alat kerja.

Dengan adanya sistem zona pada pekerjaan konstruksi juga dapat mempermudah dalam mengontrol pengadaan beton, pengaturan pekerjaan di lapangan dapat lebih terarah, pengecekan terhadap mutu yang lebih mudah.

\section{Biaya Proyek}

Biaya proyek terdiri dari biaya langsung dan biaya tidak langsung. Biaya langsung proyek adalah biaya yang diperlukan untuk menyelesaikan kegiatan-kegiatan proyek seperti pekerjaan bekisting. Biaya langsung terdiri dari: biaya bahan atau material, biaya upah tenaga kerja, dan biaya penggunaan peralatan. Sedangkan biaya tidak langsung proyek merupakan biaya yang tidak langsung berkaitan dengan penyelesaian suatu pekerjaan proyek.

\section{Motion and Time Study}

Motion and time study adalah kegiatan untuk menentukan durasi pelaksanaan suatu kegiatan kerja yang dilakukan oleh seorang operator dalam kondisi dan tempo kerja yang normal. Pelaksanaan pengukuran durasi kerja dengan metode motion and time study perlu untuk memperhatikan beberapa kriteria seperti pekerjaan yang diamati adalah pekerjaan yang pelaksanaannya berulang dan beragam, hasil dari kerja harus dapat dihitung baik secara keseluruhan maupun tiap-tiap elemen kerja (Wignjosoebroto, 1995). Prosedur yang digunakan dalam metode time study adalah standard time yang dapat ditentukan dengan menggunakan metode motion and time study dalam bentuk waktu menit yang dibutuhkan pekerja ahli, terlatih, dan berpengalaman dalam mengerjakan suatu pekerjaan dalam waktu normal (Barnes, 1980).

Kecepatan dari seorang pekerja selama studi waktu disesuaikan dengan peringkatnya dalam mengerjakan suatu pekerjaan dengan waktu normal. Waktu normal adalah waktu yang dicatat berdasarkan peringakt kinerja pekerja.

$$
\text { Waktu normal }=\text { waktu pengamatan }+(\text { waktu pengamatan } x \text { peringkat })
$$

Peringkat merupakan sebuah sebuah proses selama analisis studi waktu yang membandingkan kinerja pekerja yang diamati dengan konsep pengamat sendiri tentang kinerja normal. Peringkat dapat diukur dengan menggunakan sistem Westinghouse berdasarkan 4 faktor yang tertera pada Tabel 1. 
Tabel 1. Faktor Pengukuran Peringkat Kerja

\begin{tabular}{|c|c|c|c|c|c|c|c|c|c|c|c|}
\hline \multicolumn{3}{|c|}{ Skill } & \multicolumn{3}{|c|}{ Effort } & \multicolumn{4}{|c|}{ Conditions } & \multicolumn{2}{|c|}{ Consistency } \\
\hline+0.15 & A1 & Superskill & +0.13 & A1 & Superskill & +0.06 & A & Ideal & +0.04 & A & Ideal \\
\hline+0.13 & $\mathrm{~A} 2$ & & +0.12 & A2 & & +0.04 & $\mathrm{~B}$ & Excellent & +0.03 & $\mathrm{~B}$ & Excellent \\
\hline+0.11 & $\mathrm{~B} 1$ & Excellent & +0.10 & B1 & Excellent & +0.02 & $\mathrm{C}$ & Good & +0.01 & $\mathrm{C}$ & Good \\
\hline+0.08 & $\mathrm{~B} 2$ & & +0.08 & B2 & & 0 & $\mathrm{D}$ & Average & 0.00 & $\mathrm{D}$ & Average \\
\hline+0.06 & C1 & Good & +0.05 & $\mathrm{C} 1$ & Good & -0.03 & $\mathrm{E}$ & Fair & -0.02 & $\mathrm{E}$ & Fair \\
\hline+0.03 & $\mathrm{C} 2$ & & +0.02 & $\mathrm{C} 2$ & & -0.07 & $\mathrm{~F}$ & Poor & -0.04 & $\mathrm{~F}$ & Poor \\
\hline 0.00 & $\mathrm{D}$ & Average & 0.00 & $\mathrm{D}$ & Average & & & & & & \\
\hline-0.05 & E1 & Fair & -0.04 & E1 & Fair & & & & & & \\
\hline-0.10 & E2 & & -0.08 & E2 & & & & & & & \\
\hline-0.16 & $\mathrm{~F} 1$ & Poor & -0.12 & F1 & Poor & & & & & & \\
\hline-0.22 & $\mathrm{~F} 2$ & & -0.17 & $\mathrm{~F} 2$ & & & & & & & \\
\hline
\end{tabular}

(Sumber: Barnes, 1980)

Selain perhitungan waktu normal juga dibutuhkan tingkat kelonggaran selama mengerjakan suatu pekerjaan. Studistudi telah menunjukkan bahwa dibutuhkan 5 persen kelonggaran untuk waktu pribadi pekerja. Waktu normal yang ditambahkan dengan kelonggaran untuk waktu personal menjadikannya sebagai waktu standar untuk menyelesaikan sutau pekerjaan, (Barnes, 1980). Faktor kelonggaran tersebut merupakan faktor toleransi yang diambil sebsesar $5 \%$.

$$
\text { Waktu standar }=\text { waktu normal }+(\text { waktu normal } x \text { faktor toleransi })
$$

\section{Analisis Harga Satuan Pekerjaan dan Koefisien Tenaga Kerja}

Analisis harga satuan pekerjaan adalah perhitungan kebutuhan biaya tenaga kerja, bahan, dan peralatan untuk mendapatkan harga satuan atau satu jenis pekerjaan tertentu. Umumnya analisis yang dilakukan merupakan perhitungan untuk mendapatkan biaya yang dibutuhkan untuk menyelesaikan satu satuan volume pekerjaan yang merupakan analisis terhadap perhitungan produktivitas tenaga kerja, peralatan, dan material yang dibutuhkan (Permen Pekerjaan Umum Nomor 11/PRT/M/2013). Untuk satu satuan volume pekerjaan tertentu dapat dihitung koefisien kebutuhan tenaga kerja yang dirumuskan sebagai berikut:

Untuk pekerjaan $1 \mathrm{~m}^{2}$ :

$$
\begin{aligned}
& \text { Pekerja }=(T k x P) / Q t ; \text { Orang-Jam } \\
& \text { Mandor }=(T k x M) / Q t ; \text { Orang-Jam }
\end{aligned}
$$

Kerterangan:

Produksi / hari: $Q t=T k x Q 1$ (m² / waktu pekerjaan); $\mathrm{m}^{2}$

$\mathrm{P}$ adalah jumlah pekerja yang diperlukan.

$\mathrm{T}_{\mathrm{k}}$ adalah jumlah jam kerja efektif 1 hari (7 jam)

M adalah jumlah mandor yang diperlukan.

\section{Bekisting}

Bekisting merupakan komponen struktur sementara yang digunakan sebagai cetakan untuk membentuk beton segar yang diinginkan dan sebagai pemikul beban-beban yang diterimanya seperti alat-alat pembekistingan, beban tukang, beton yang belum mengeras untuk merealisasikan struktur suatu bangunan agar sesuai dengan rencana, (Wigbout, 1992).

Perkembangan bekisting menurut Wigbout (1992) terdiri dari:

1. Bekisting konvensional

Bekisting konvensional merupakan bekisting yang bahannya terdiri dari papan dan kayu balok yang pengerjaan untuk bekistingnya diperlukan tukang-tukang kayu yang ahli. Bekisting konvensional hanya dapat beberapa kali pemakaian saja. Bekisting konvensional dikenal juga dengan bekisting tradisional yang setelah diinstalasi dan dibongkar menjadi bahan-bahan dasar kembali, bahan dasar tersebut dapat disusun menjadi bentuk struktur lain lagi.

2. Bekisting setengah sistem 
Merupakan bekisting yang dimensinya telah ditentukan sesuai dengan detail elemen struktur yang akan didirikan.

3. Bekisting sistem

Bekisting sistem merupakan bekisting prepabrikasi yang pada awalnya sebagian besar komponennya terbuat dari baja atau aluminium. Penggunaan bekisting sistem ditujukan untuk penggunaan berulang pada suatu proyek dengan dimensi elemen struktur yang sama. Untuk proses pengerjaan menggunakan bekisting sistem dapat sedikit mengurangi penggunaan alat berat karena proses pengerjaan yang lebih ringan dengan adanya elemen-elemen pembantu yang sederhana serta mudah untuk dikerjakan. Tetapi penggunaan bekisting sistem ini diperlukan investas awal yang cukup tinggi.

\section{METODE PENELITIAN}

\section{Lokasi Penelitian}

Penelitian dilakukan pada proyek bangunan tinggi yang berkonsep TOD (Transit Oriented Development), yaitu konsep berbasis transportasi yang mengintegrasikan antara hunian dan moda transportasi umum. Proyek yang akan diteliti adalah proyek X beralamat di kota Tangerang Selatan, sedangkan dalam melakukan penelitian untuk diperlukan pengamatan terlebih dahulu pada proyek yang sudah menggunakan bekisting aluminium yaitu proyek Y yang beralamat di Kota Depok.

\section{Pengumpulan Data}

Pengumpulan data yang dilakukan untuk penelitian ini adalah data dari proyek X dan proyek Y.

Data yang dikumpulkan dari proyek $\mathrm{X}$ antara lain:

1. Jadwal rencana proyek $X$.

2. Detail pekerjaan struktur atas.

3. Denah proyek dan zonasi pekerjaan bekisting.

4. Biaya pekerjaan bekisting.

Data yang dikumpulkan dari proyek Y antara lain:

1. Detail pekerjaan struktur atas.

2. Denah proyek dan zonasi pekerjaan bekisting.

\section{Pengamatan Lapangan}

Pengamatan lapangan pada proyek Y difokuskan pada pekerjaan bekisting struktur atas yang terdiri dari:

1. Tahapan dalam pekerjaan pemasangan dan pembongkaran bekisting aluminium untuk elemen struktur atas yang terdiri dari kolom, balok, plat lantai, dan dinding.

2. Waktu yang dibutuhkan untuk pekerjaan pemasangan dan pembongkaran bekisting kolom, balok, plat lantai, dan dinding.

3. Jumlah tenaga kerja yang diperlukan untuk pekerjaan pemasangan dan pembongkaran bekisting.

Hasil pengamatan akan dilampirkan dalam bentuk tabel 2 berikut.

Tabel 2. Hasil Pengamatan Pekerjaan Bekisting

\begin{tabular}{|c|c|c|c|c|c|c|c|}
\hline & $\mathrm{PE}$ & ERJAAN & EKISTII & ALUMINIUM & & $\begin{array}{c}\text { Elemen } \\
\text { Struktur: }\end{array}$ & \\
\hline \multirow{2}{*}{ No. } & \multirow{2}{*}{ Kegiatan } & Mulai & Selesai & Waktu Pengamatan & Luas & Jumlah Pekerja & \multirow{2}{*}{ Keterangan } \\
\hline & & (pukul) & (pukul) & (menit) & $\left(\mathrm{m}^{2}\right)$ & (org) & \\
\hline \multicolumn{8}{|l|}{1} \\
\hline \multicolumn{8}{|l|}{2} \\
\hline
\end{tabular}

\section{Perhitungan}

Berdasarkan hasil pengamatan, data-data tersebut dijadikan sebagai dasar perhitungan untuk mengetahui:

1. Durasi total proyek.

2. Biaya pekerjaan bekisting dengan menggunakan nilai kontrak untuk biaya bekisting konvensional dan hasil perhitungan koefisien tenaga kerja untuk biaya bekisting aluminium. 


\section{Perhitungan Durasi Proyek}

Perhitungan durasi proyek untuk mengetahui durasi total proyek $\mathrm{X}$ dan pencapaian target waktu selesainya pekerjaan struktur atas dengan penggunaan bekisting aluminium. Perhitungan durasi proyek X untuk pekerjaan struktur atas yang menggunakan bekisting aluminium dilakukan dengan 2 simulasi pembagian zona, yaitu 6 zona dan 8 zona yang durasi pekerjaannya berdasarkan hasil pengamatan pekerjaan bekisting di proyek Y. Setelah didapat durasi pekerjaan struktur atas proyek X, selanjutnya dengan menggunakan program Ms. Project dilakukan penjadwalan kembali kegiatan proyek X untuk mengetahui durasi total proyek dan kapan pekerjaan struktur atas dapat diselesaikan.

\section{Perhitungan Koefisien Tenaga Kerja Bekisting Aluminium}

Pekerjaan bekisting aluminium meliputi pekerjaan pemasangan dan pembongkaran bekisting sehingga diperlukan perhitungan koefisien tenaga kerja untuk pekerjaan pemasangan dan pembongkaran bekisting. Dalam menghitung koefisien tenaga kerja pekerjaan bekisting aluminum, dibutuhkan data berupa: waktu pengerjaan yang dihitung dengan metode motion and time study, luas, dan jumlah tenaga kerja.

\section{Perhitungan Waktu Standar}

Dari hasil pengamatan didapatkan waktu pengamatan yang kemudian dilakukan perhitungan untuk mendapatkan waktu standar pekerjaan bekisting aluminum dengan menggunakan metode motion and time study. Waktu standar adalah waktu yang diperlukan untuk menyelesaikan suatu luasan pekerjaan dengan memberikan toleransi kepada pekerja sebesar 5 persen.

Untuk menghitung waktu standar, diperlukan nilai waktu normal yang dihitung berdasarkan waktu pengamatan dengan memberikan peringkat kinerja pekerja. Peringkat kinerja pekerja tersebut merupakan 4 faktor yang dijumlahkan sesuai dengan tabel 1. Rumus untuk menghitung waktu standar dan waktu normal adalah sebagai berikut:

$$
\begin{gathered}
\text { Waktu normal }=\text { Waktu pengamatan }+(\text { Waktu pengamatan } X \text { Peringkat }) \\
\text { Waktu standar }=\text { Waktu normal }+
\end{gathered}
$$

\section{Perhitungan Koefisien Tenaga Kerja Pemasangan dan Pembongkaran Bekisting Aluminium}

Setelah didapat waktu standar pekerjaan bekisting aluminium, selanjutnya dapat dihitung koefisien tenaga kerja pemasangan dan pembongkaran bekisting aluminium. Menurut Undang-Undang No.13 tahun 2003 tentang Ketenagakerjaan pasal 77, 1 hari kerja efektif untuk para pekerja adalah 7 jam. Sedangkan perhitungan untuk nilai koefisien tenaga kerja kegiatan $1 \mathrm{~m}^{2}$ bekisting aluminium yang dihitung sesuai dengan rumus 3 dan 4 memiliki satuan orang-jam $/ \mathrm{m}^{2}$, sehingga perlu mengubah satuannya menjadi orang-hari $/ \mathrm{m}^{2}$ dengan membagi koefisien menjadi 7 jam. Sehingga koefisien tenaga kerja dapat dihitung sebagai berikut:

$$
\begin{aligned}
& \text { Koefisien pekerja (Orang-Hari) }=\frac{\text { JumlahjamkerjaXJumlahpekerja }}{\text { LuasX7 }} \\
& \text { Koefisien mandor (Orang-Hari) }=\frac{\text { JumlahjamkerjaXJumlahmandor }}{\text { Luas } X 7}
\end{aligned}
$$

\section{Perhitungan Biaya Pekerjaan Bekisting}

Perhitungan biaya pekerjaan bekisting dilakukan untuk penggunaan bekisting konvensional dan bekisting aluminium. Biaya pekerjaan bekisting yang dimaksud yaitu total biaya pengadaan material bekisting, dan biaya upah tenaga kerja bekisting.

Biaya upah tenaga kerja bekisting merupakan total biaya upah untuk pekerja, tukang, dan mandor yang merupakan satu kesatuan kelompok kerja dalam pekerjaan bekisting. Biaya upah tenaga kerja didasari oleh analisis harga satuan upah tenaga kerja yang memerlukan hasil perhitungan koefisien tenaga kerja pekerjaan bekisting untuk setiap elemen struktur atas yang diamati.

Perhitungan biaya tenaga kerja pekerjaan bekisting digunakan tabel analisis harga satuan tenaga kerja yang dapat dilihat pada Tabel 3 . 
Tabel 3. Analisis Harga Satuan Tenaga Kerja Bekisting Aluminium

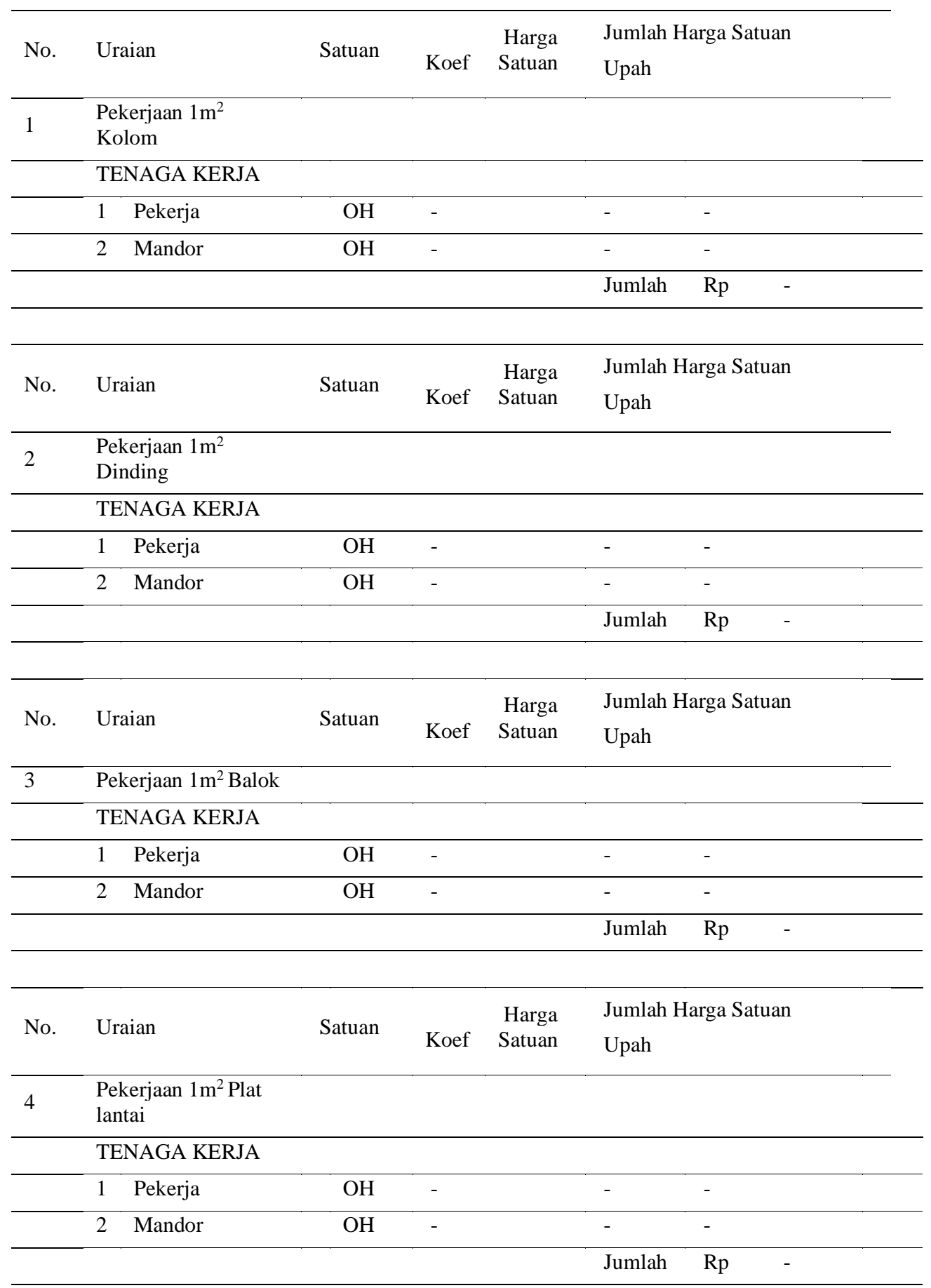

(Sumber: Peraturan Menteri Pekerjaan Umum, 2013)

\section{Analisis Hasil Perhitungan}

Setelah didapatkan durasi dan biaya pekerjaan bekisting aluminium dari perhitungan, selanjutnya dilakukan analisis hasil perhitungan durasi dan biaya pekerjaan bekisting aluminium dan konvensional.

Analisis dilakukan dengan membandingkan penggunaan bekisting konvensional dengan penggunaan bekisting aluminium terhadap durasi yang diperlukan dan biaya yang dikeluarkan. Hasil analisis ini nantinya dapat dijadikan 
sebagai dasar bagi pihak owner untuk mengambil keputusan terhadap metode percepatan yang akan digunakan pada proyek X seperti yang diperlihatkan pada Gambar 2.

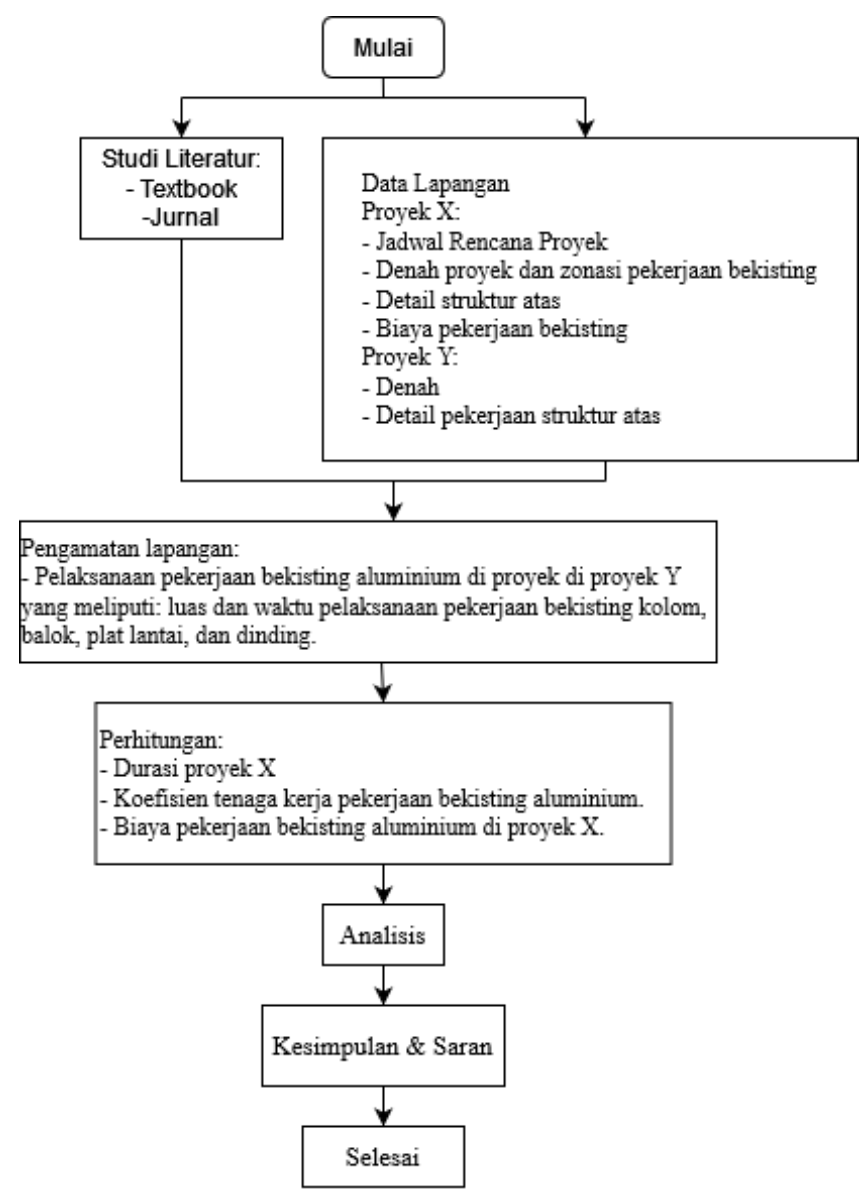

Gambar 2. Diagram Alir Penelitian

\section{HASIL DAN PEMBAHASAN}

Dari hasil pengumpulan data lapangan, didapatkan data umum proyek X sebagai berikut:
1. Peruntukan
: Rumah susun
2. Lokasi
: Jl. Raya Rawa Buntu. Kecamatan Serpong, Kota Tangerang Selatan
3. Luas area proyek : $2.4626 \mathrm{Ha}$
4. Luas bangunan
: $8.5958 \mathrm{Ha}$
5. Jumlah lantai
: 34 lantai

Jadwal rencana proyek dengan menggunakan bekisting konvensional adalah sebagai berikut:
1. Tanggal pelaksanaan
2. Durasi proyek
: 19 Juli 2019 - 29 Agustus 2021.
3. Waktu selesai pekerjaan struktur atas
: 745 hari.
: Oktober 2020.

Jadwal rencana proyek dengan menggunakan beksiting aluminium adalah sebagai berikut:

1. Tanggal pelaksanaan

2. Durasi proyek

3. Waktu selesai pekerjaan struktur atas
: 19 Juli 2019 - 29 Juli 2021.

: 714 hari kalender.

: September 2020.

Pelaksanaan proyek dimulai sesuai jadwal rencana yaitu 19 Juli 2019, namun terjadi mundurnya waktu mulai pelaksanaan relokasi stasiun existing karena adanya kendala izin pelaksanaan relokasi tersebut. Sehingga perlu dilakukan revisi atau perubahan jadwal rencana untuk mengetahui durasi proyek dan kapan proyek dapat diselesaikan. 
Jadwal rencana revisi 1 adalah sebagai berikut:

1. Tanggal pelaksanaan

2. Durasi proyek

3. Waktu selesai pekerjaan struktur atas
: 19 Juli 2019 - 29 Agustus 2021.

: 745 hari kalender.

: Oktober 2020.

Dari hasil penjadwalan rencana revisi 1 didapat total durasi proyek dan waktu penyelesaian pekerjaan struktur atas lebih dari jangka waktu yang diberikan oleh owner, maka perlu dilakukan percepatan agar dapat menyelesaikan proyek tepat waktu. Salah satu percepatan yang dilakukan adalah dengan mengganti metode pelaksanaan pekerjaan struktur atas yaitu dengan mengganti penggunaan bekisting konvensional menjadi bekisting aluminium. Sehingga perlu dilakukan analisis lebih lanjut mengenai pengaruh penggantian bekisting konvensioal yang direncanakan pada proyek $\mathrm{X}$ dengan terlebih dahulu dilakukan pengamatan lapangan pada proyek yang telah menggunakan bekisting aluminium, yaitu proyek Y.

\section{Data Hasil Pengamatan}

Hasil pengamatan waktu pekerjaan beksiting aluminium proyek Y untuk zona 9 dan 10 dengan luas $462.9704 \mathrm{~m}^{2}$ adalah 4 hari. Sedangkan waktu pekerjaan besi dan pekerjaan cor dibutuhkan 2 hari, sehingga total waktu pekerjaan strukturnya adalah 6 hari.

\section{Hasil Pengamatan Pekerjaan Bekisting Struktur Atas}

Pada pekerjaan pemasangan bekisting kolom, dinding, balok, dan plat lantai masing-masing diperlukan 1 orang mandor dan 2 orang pekerja yang kegiatannya adalah memasang panel kolom dan memasang sabuk kolom. Contoh hasil pengamatan pekerjaan bekisting struktur atas terdapat pada Tabel 4 s.d. Tabel 7.

Tabel 4. Contoh Hasil Pengamatan Kolom

\begin{tabular}{|c|c|c|c|c|c|c|c|}
\hline \multicolumn{7}{|c|}{ PEKERJAAN BEKISTING ALUMINUM } & \multirow[t]{2}{*}{ Elemen: Kolom } \\
\hline No. & Kegiatan & $\begin{array}{l}\text { Mulai } \\
\text { (Pukul) }\end{array}$ & $\begin{array}{l}\text { Selesai } \\
\text { (Pukul) }\end{array}$ & $\begin{array}{l}\text { Waktu } \\
\text { (menit) }\end{array}$ & $\begin{array}{l}\text { Luas } \\
\left(\mathrm{m}^{2}\right)\end{array}$ & $\begin{array}{l}\text { Pekerja } \\
\text { (org) }\end{array}$ & \\
\hline \multirow[t]{4}{*}{1} & Kolom & & & & & & Semua panel tersedia \\
\hline & Pemasangan panel & 14.56 & 15.13 & 17 & \multirow[b]{2}{*}{10.8} & \multirow[b]{2}{*}{2} & Zona 10 \\
\hline & $\begin{array}{l}\text { Pemasangan sabuk } \\
\text { kolom }\end{array}$ & 15.13 & 15.26 & 13 & & & \\
\hline & & & Total & 30 & & & \\
\hline
\end{tabular}

\begin{tabular}{lllllll}
2 & Kolom & & & & $\begin{array}{c}\text { Ada 1 panel yang } \\
\text { harus dibersihkan }\end{array}$ \\
\cline { 1 - 5 } Pemasangan panel & 15.01 & 15.30 & 19 & 10.8 & 2 \\
$\begin{array}{l}\text { Pemasangan sabuk } \\
\text { kolom }\end{array}$ & 15.20 & 15.35 & 15 & & Zona 10 \\
\hline
\end{tabular}

Tabel 5. Contoh Hasil Pengamatan Dinding

\begin{tabular}{|c|c|c|c|c|c|c|c|}
\hline \multicolumn{7}{|c|}{ PEKERJAAN BEKISTING ALUMINUM } & \multirow{2}{*}{$\begin{array}{l}\text { Elemen: Dinding } \\
\text { Keterangan }\end{array}$} \\
\hline No. & Kegiatan & $\begin{array}{l}\text { Mulai } \\
\text { (Pukul) }\end{array}$ & $\begin{array}{l}\text { Selesai } \\
\text { (Pukul) }\end{array}$ & $\begin{array}{l}\text { Waktu } \\
\text { (menit) }\end{array}$ & $\begin{array}{l}\text { Luas } \\
\left(\mathrm{m}^{2}\right)\end{array}$ & $\begin{array}{l}\text { Pekerja } \\
\text { (org) }\end{array}$ & \\
\hline \multirow[t]{2}{*}{1} & Dinding & & & & & & \multirow{2}{*}{$\begin{array}{l}\text { Semua panel } \\
\text { tersedia }\end{array}$} \\
\hline & Pemasangan panel & 15.33 & 15.43 & 10 & 6.51 & 2 & \\
\hline \multirow[t]{2}{*}{2} & Dinding & & & & & & \multirow{2}{*}{$\begin{array}{l}\text { Semua panel } \\
\text { tersedia }\end{array}$} \\
\hline & Pemasangan panel & 15.51 & 16.00 & 9 & 7.5 & 2 & \\
\hline
\end{tabular}


Tabel 6. Contoh Hasil Pengamatan Balok

\begin{tabular}{|c|c|c|c|c|c|c|c|}
\hline \multicolumn{7}{|c|}{ PEKERJAAN BEKISTING ALUMINUM } & Elemen: Balok \\
\hline No. & Kegiatan & $\begin{array}{l}\text { Mulai } \\
\text { (Pukul) }\end{array}$ & $\begin{array}{l}\text { Selesai } \\
\text { (Pukul) }\end{array}$ & $\begin{array}{l}\text { Waktu } \\
\text { (menit) }\end{array}$ & $\begin{array}{l}\text { Luas } \\
\left(\mathrm{m}^{2}\right)\end{array}$ & $\begin{array}{l}\text { Pekerja } \\
\text { (org) }\end{array}$ & Keterangan \\
\hline \multirow[t]{4}{*}{1} & Balok & & & & & & \\
\hline & Pemasangan bot-beam & 08.17 & 08.29 & 12 & \multirow{2}{*}{3.84} & \multirow{2}{*}{2} & Zona 10 \\
\hline & Pemasangan side-beam & 08.31 & 08.46 & 15 & & & Semua panel tersedia \\
\hline & & & Total & 27 & & & \\
\hline \multirow[t]{4}{*}{2} & Balok & & & & & & \\
\hline & Pemasangan bot-beam & 08.19 & 08.40 & 21 & \multirow{2}{*}{8.56} & \multirow{2}{*}{2} & Zona 10 \\
\hline & Pemasangan side-beam & 08.40 & 09.15 & 35 & & & Semua panel tersedia \\
\hline & & & Total & 56 & & & \\
\hline
\end{tabular}

Tabel 7. Contoh Hasil Pengamatan Plat Lantai

\begin{tabular}{|c|c|c|c|c|c|c|c|}
\hline \multicolumn{7}{|c|}{ PEKERJAAN BEKISTING ALUMINUM } & \multirow[t]{2}{*}{ Elemen: Plat lantai } \\
\hline No. & Kegiatan & $\begin{array}{l}\text { Mulai } \\
\text { (Pukul) }\end{array}$ & $\begin{array}{l}\text { Selesai } \\
\text { (Pukul) }\end{array}$ & $\begin{array}{l}\text { Waktu } \\
\text { (menit) }\end{array}$ & $\begin{array}{l}\text { Luas } \\
\left(\mathrm{m}^{2}\right)\end{array}$ & $\begin{array}{l}\text { Pekerja } \\
\text { (org) }\end{array}$ & \\
\hline \multirow[t]{4}{*}{1} & Plat Lantai & & & & & & \\
\hline & Pemasangan SC & 08.03 & 09.00 & 57 & \multirow[b]{2}{*}{9.06} & & \multirow{2}{*}{$\begin{array}{l}\text { Zona } 10 \\
\text { Semua panel tersedia }\end{array}$} \\
\hline & $\begin{array}{l}\text { Pemasangan } \\
\text { panel plat lantai }\end{array}$ & 09.00 & 09.13 & 13 & & 2 & \\
\hline & & & Total & 70 & & & \\
\hline \multirow[t]{4}{*}{2} & Plat Lantai & & & & & & \\
\hline & Pemasangan SC & 08.06 & 08.44 & 38 & \multirow[b]{2}{*}{9.35} & \multirow[b]{2}{*}{2} & \\
\hline & $\begin{array}{l}\text { Pemasangan } \\
\text { panel plat lantai }\end{array}$ & 08.45 & 08.58 & 13 & & & $\begin{array}{l}\text { Zona } 10 \\
\text { Membersihkan } 1 \text { panel }\end{array}$ \\
\hline & & & Total & 51 & & & \\
\hline
\end{tabular}

\section{Perhitungan Durasi Proyek X}

\section{A. Pekerjaan struktur atas dengan 6 zona}

Berdasarkan hasil pengamatan zona 9 dan 10 proyek Y, perhitungan durasi pekerjaan struktur atas proyek X dengan pembagian 6 zona membutuhkan 5 hari untuk tiap zonanya, dengan perincian 3 hari untuk pekerjaan bekisting dan 2 hari untuk pekerjaan tulangan dan pengecoran. Selanjutnya digunakan program Microsoft Project untuk mengetahui durasi proyek dan kapan proyek dapat diselesaikan. Berikut merupakan hasil penjadwalan proyek X untuk pembagian 6 zona:

1. Tanggal pelaksanaan proyek

2. Durasi proyek

3. Waktu selesai pekerjaan struktur atas
: 19 Juli 2019 - 13 Agustus 2021.

: 729 hari kalender.

: September 2020.

B. Pekerjaan struktur atas dengan 8 zona

Berdasarkan hasil pengamatan zona 9 dan 10 proyek Y, perhitungan durasi pekerjaan struktur atas proyek X dengan pembagian 6 zona membutuhkan 4 hari untuk tiap zonanya, dengan perincian 2 hari untuk pekerjaan bekisting dan 2 hari untuk pekerjaan tulangan dan pengecoran. Selanjutnya digunakan program Microsoft Project untuk mengetahui durasi proyek dan kapan proyek dapat diselesaikan. Berikut merupakan hasil penjadwalan proyek X untuk pembagian 8 zona:

1. Tanggal pelaksanaan proyek

: 19 Juli 2019 - 26 Juli 2021. 
2. Durasi proyek

3. Waktu selesai pekerjaan struktur atas
: 711 hari kalender.

: Agustus 2020.

\section{Perhitungan Waktu Standar}

Perhitungan waktu standar pekerjaan bekisting memerlukan data waktu pengamatan setiap elemen struktur yang diamati. Contoh data waktu pengamatan kolom terdapat pada tabel 8.

\begin{tabular}{ccc}
\hline $\begin{array}{c}\text { Luas } \\
\left(\mathrm{m}^{2}\right)\end{array}$ & Kegiatan & $\begin{array}{c}\text { Waktu pengamatan } \\
\text { (menit) }\end{array}$ \\
\hline \multirow{2}{*}{10,8} & Memasang panel & 17 \\
\cline { 2 - 3 } & Memasang sabuk & 13 \\
\hline
\end{tabular}

Tabel 8. Data Waktu Pengamatan Kolom

Dari waktu pengamatan, selanjutnya dihitung waktu normal dengan memperhatikan faktor peringkat kerja sesuai dengan tabel 1 untuk para pekerja. Faktor peringkat kerja tersebut terdiri dari 4 faktor yang kemudian dijumlahkan sesuai dengan pengamatan terhadap para pekerja, hasil pengamatan serta perhitungannya sebagai berikut:

1. Kemampuan kerja

$$
\begin{array}{ll}
=\text { good } & =0,06 \\
=\text { good } & =0,05 \\
=\text { average } & =0 \\
=\text { good } & =0,01 \\
\quad \text { Total } & =0,12
\end{array}
$$

Sesuai rumus 5, maka waktu normal pekerjaan bekisting kolom pada tabel 8 dapat dihitung sebagai berikut:

Waktu normal (memasang panel) $=17+(17 \times 0.12)=19,04$ menit

Waktu normal (memasang sabuk) $=13+(13 \times 0.12)=14,56$ menit

Selanjutnya dengan memperhatikan faktor toleransi sesuai rumus 6 dapat dihitung waktu standar pekerjaan bekisting kolom pada tabel 8 sebagai berikut:

Waktu standar (memasang panel $)=19,04+(19.04 \times 0.05)=19,992$ menit

\begin{tabular}{|c|c|c|c|c|c|c|c|}
\hline \multicolumn{8}{|c|}{ WAKTU STANDAR } \\
\hline Elemen: & Kolom & & & & & & \\
\hline No. & $\begin{array}{l}\text { Luas } \\
\left(\mathrm{m}^{2}\right)\end{array}$ & Kegiatan & $\begin{array}{c}\text { Waktu } \\
\text { pengamatan } \\
\text { (menit) }\end{array}$ & $\begin{array}{l}\text { Waktu } \\
\text { Normal } \\
\text { (menit) }\end{array}$ & $\begin{array}{l}\text { Waktu } \\
\text { Standar } \\
\text { (menit) }\end{array}$ & $\begin{array}{c}\text { Waktu } \\
\text { Standar } \\
\text { (jam) }\end{array}$ & $\begin{array}{c}\text { Total } \\
\text { waktu } \\
\text { standar } \\
\text { (jam) }\end{array}$ \\
\hline \multirow{2}{*}{1} & \multirow{2}{*}{10.8} & Memasang panel & 17 & 19,04 & 19,992 & 0,3332 & \multirow{2}{*}{0,588} \\
\hline & & Memasang sabuk & 13 & 14,56 & 15,288 & 0,2548 & \\
\hline
\end{tabular}

Waktu standar $($ memasang sabuk $)=14,56+(14.56 \times 0.05)=15,288$ menit

Sehingga waktu standar yang dibutuhkan untuk menyelesaikan pekerjaan bekisting aluminium kolom adalah $19,992+15,288=35,28$ menit $=0,588$ jam.

Tabel 9. Contoh Perhitungan Waktu Standar Pemasangan Bekisting Kolom

\section{Perhitungan Koefisien Tenaga Kerja Pemasangan Bekisting Aluminium}

Setelah melakukan perhitungan waktu standar untuk masing-masing elemen struktur, selanjutnya dapat dihitung nilai koefisien tenaga kerja pemasangan bekisting aluminium. Berdasarkan tabel 9, berikut merupakan contoh perhitungan koefisien tenaga kerja pemasangan bekisting kolom sesuai rumus 7 dan 8 .

Koefisien pekerja (Orang-Hari) $=\frac{0.588 \times 2}{10,8 \times 7}=0,0156 \mathrm{OH}$

Koefisien mandor (Orang-Hari) $=\frac{0.588 \times 1}{10,8 \times 7}=0,0078 \mathrm{OH}$ 
Perhitungan untuk setiap elemen struktur yang diamati dilakukan dengan cara yang sama seperti diatas yang selanjutnya dihitung rata-rata nilai koefisien tenaga kerja untuk setiap elemen struktur yang diamati tersebut. Nilai koefisien tenaga kerja pemasangan bekisting aluminium dengan jumlah pekerja bekisting vertikal 2 orang dan bekisting horizontal 2 orang serta 1 mandor untuk masing-masing pekerjaan adalah sebagai berikut:

1. Pemasangan $1 \mathrm{~m}^{2}$ bekisting aluminium kolom:

Koefisien pekerja = 0,1089 OH (Orang-Hari)

Koefisien mandor= 0,0545 OH (Orang-Hari)

2. Pemasangan $1 \mathrm{~m}^{2}$ bekisting aluminium dinding:

Koefisien pekerja $=0,1089 \mathrm{OH}$ (Orang-Hari)

Koefisien mandor= 0,0545 OH (Orang-Hari)

3. Pemasangan $1 \mathrm{~m}^{2}$ bekisting aluminium balok:

Koefisien pekerja $=0,2307 \mathrm{OH}$ (Orang-Hari)

Koefisien mandor= 0,1154 OH (Orang-Hari)

4. Pemasangan $1 \mathrm{~m}^{2}$ bekisting aluminium plat:

Koefisien pekerja $=0,1144 \mathrm{OH}$ (Orang-Hari)

Koefisien mandor= 0,0572 OH (Orang-Hari)

\section{Perhitungan Koefisien Tenaga Kerja Pembongkaran Bekisting Aluminium}

Selain pekerja dan mandor untuk pemasangan bekisting aluminium dibutuhkan juga pekerja untuk pembongkaran bekisting aluminium yang terdiri dari 6 orang. Perhitungan nilai koefisien tenaga kerja untuk pekerjaan pembongkaran bekisting aluminium adalah sebagai berikut:

1. Koefisien tenaga kerja vertikal: (6 orang $\mathrm{x} 1$ hari kerja) $/ 186,965 \mathrm{~m}^{2}=0,0321 \mathrm{OH}$

2. Koefisien tenaga kerja plat lantai: (6 orang $x 1$ hari kerja) $/ 140,9704 \mathrm{~m}^{2}=0,0426 \mathrm{OH}$

3. Koefisien tenaga kerja balok: (6 orang x 1 hari kerja) $/ 134,7 \mathrm{~m}^{2}=0,0445 \mathrm{OH}$

\section{Perhitungan Biaya Pekerjaan Bekisting}

A. Biaya pekerjaan bekisting aluminium

Biaya pekerjaan bekisting aluminium terdiri dari biaya pengadaan material sebesar USD 140.00 atau Rp 1,964,200.00 untuk $1 \mathrm{~m}^{2}$ pekerjaan bekisting aluminium. (Sumber: Penyedia material bekisting aluminium brand $\mathrm{X}$, yang digunakan pada proyek $\mathrm{X}$ ). Berikut merupakan perhitungan biaya pengadaan material bekisting aluminium.

Tabel 10. Perhitungan Biaya Pengadaan Material Bekisting Aluminium

\begin{tabular}{llllll}
\hline \multirow{2}{*}{$\begin{array}{l}\text { Elemen } \\
\text { Struktur }\end{array}$} & \multicolumn{1}{c}{ Luas } & \multicolumn{3}{c}{ Biaya } \\
\cline { 2 - 6 } & \multicolumn{1}{c}{$\left(\mathrm{m}^{2}\right)$} & \multicolumn{2}{c}{$1 \mathrm{~m}^{2}$} \\
\hline Kolom & 265,32 & $\mathrm{Rp}$ & $1.964 .200,00$ & $\mathrm{Rp}$ & $521.141 .544,00$ \\
\hline Balok & $2 \times 359,73$ & $\mathrm{Rp}$ & $1.964 .200,00$ & $\mathrm{Rp}$ & $1.413 .178 .259,92$ \\
\hline Lantai & $2 \times 822,26$ & $\mathrm{Rp}$ & $1.964 .200,00$ & $\mathrm{Rp}$ & $3.230 .178 .467,59$ \\
\hline Tangga & 56,30 & $\mathrm{Rp}$ & $1.964 .200,00$ & $\mathrm{Rp}$ & $110.585 .266,07$ \\
\hline Dinding & 567,08 & $\mathrm{Rp}$ & $1.964 .200,00$ & $\mathrm{Rp}$ & $1.113 .865 .175,00$ \\
\hline & & Jumlah & $\mathrm{Rp}$ & $6.388 .948 .713,00$ \\
\hline
\end{tabular}

Biaya total untuk pengadaan material bekisting aluminium pada proyek X adalah Rp 6,388,948,713.00.

Sedangkan biaya upah tenaga kerja untuk $1 \mathrm{~m}^{2}$ pekerjaan bekisting aluminium didapat dari harga satuan tenaga kerja yang dihitung dengan menggunakan tabel 3. Dari hasil perhitungan, harga satuan upah tenaga kerja bekisting aluminium adalah sebagai berikut:Pekerjaan pemasangan $1 \mathrm{~m}^{2}$ bekisting aluminium kolom

$=\operatorname{Rp} 18,723.30$

4. Pekerjaan pemasangan $1 \mathrm{~m}^{2}$ bekisting aluminium dinding

5. Pekerjaan pemasangan $1 \mathrm{~m}^{2}$ bekisting aluminium lantai 
6. Pekerjaan pemasangan $1 \mathrm{~m}^{2}$ bekisting aluminium balok

7. Pekerjaan pembongkaran $1 \mathrm{~m}^{2}$ bekisting aluminium kolom

8. Pekerjaan pembongkaran $1 \mathrm{~m}^{2}$ bekisting aluminium dinding

9. Pekerjaan pembongkaran $1 \mathrm{~m}^{2}$ bekisting aluminium lantai

10. Pekerjaan pembongkaran $1 \mathrm{~m}^{2}$ bekisting aluminium balok

$$
\begin{aligned}
& =\operatorname{Rp} 39.687,90 \\
& =\operatorname{Rp} 3.113,70 \\
& =\operatorname{Rp} 3.113,70 \\
& =\operatorname{Rp} 4.132,20 \\
& =\operatorname{Rp} 4.316,50
\end{aligned}
$$

Dengan harga satuan upah pekerja bekisting aluminium diatas, didapatkan nilai total upah pekerjaan bekisting aluminium untuk proyek X sebesar Rp 1,602,599,842.28. Sehingga total biaya pekerjaan bekisting aluminium proyek X sebesar Rp 7,991,548,555.00.

B. Biaya pekerjaan bekisting konvensional

Biaya pengadaan material dan biaya upah tenga kerja untuk $1 \mathrm{~m}^{2}$ pekerjaan bekisting konvensional pada proyek $\mathrm{X}$ adalah sebagai berikut:

$$
\begin{array}{ll}
\text { 1. Biaya pengadaan material } & =\mathrm{Rp} 70.410,00 \\
\text { 2. Biaya upah tenaga kerja } & =\mathrm{Rp} 46.020,00
\end{array}
$$

Nilai dari kedua jenis biaya tersebut merupakan nilai yang didapatkan dari nilai kontrak pembangunan proyek X. Kedua nilai tersebut digunakan sebagai harga satuan untuk perhitungan biaya pekerjaan bekisting konvensional pada proyek X. Berdasarkan nilai kontrak tersebut, diketahui total biaya untuk pengadaan material bekisting

\begin{tabular}{|c|c|c|c|c|c|}
\hline \multirow{2}{*}{$\begin{array}{l}\text { Material } \\
\text { Bekisting }\end{array}$} & \multirow{2}{*}{$\begin{array}{l}\text { Jumlah } \\
\text { Zona }\end{array}$} & \multicolumn{2}{|c|}{ Tanggal Pelaksanaan } & \multirow{2}{*}{$\begin{array}{c}\text { Durasi } \\
\text { Proye } \\
\mathrm{k} \\
\text { (hari) }\end{array}$} & \multirow{2}{*}{$\begin{array}{l}\text { Waktu Selesai } \\
\text { Struktur Atas }\end{array}$} \\
\hline & & Mulai & Selesai & & \\
\hline $\begin{array}{c}\text { Konvensiona } \\
\text { l }\end{array}$ & 2 & 19 Juli 2019 & 29 Agustus 2021 & 745 & Oktober 2020 \\
\hline \multirow{2}{*}{ Aluminium } & 6 & 19 Juli 2019 & 13 Agustus 2021 & 729 & September 2020 \\
\hline & 8 & 19 Juli 2019 & 26 Juli 2021 & 711 & Agustus 2020 \\
\hline
\end{tabular}
sebesar Rp 4,224,942,727.00 dan total biaya untuk upah tenaga kerja bekisting sebesar Rp 2,761,424,007.00. Sehingga total biaya pekerjaan bekisting konvensional proyek X adalah sebesar Rp 6,986,366,734.00.

\section{Pembahasan}

\section{A. Durasi proyek}

Dari data waktu proyek dan hasil perhitungan durasi proyek dengan simulasi pembagian 2 zona diketahui data waktu proyek X berdasarkan jenis material bekisting adalah sebagai berikut.

Tabel 11. Data Waktu Proyek X berdasarkan Jenis Material Bekisting

Pembagian 8 zona ini merupakan pembagian zona yang paling maksimum dari segi durasi pekerjaan struktur atas, karena dengan pembagian zona lebih dari 8 zona juga akan menghasilkan siklus pekerjaan struktur atas per lantai per zona adalah selama 4 hari. Sehingga pembagian 8 zona merupakan langkah percepatan pada pekerjaan struktur yang paling memungkinkan untuk mendekati target penyelesaiannya. Adapun cara agar pencapaian target pekerjaan struktur atas tercapai yaitu dengan penambahan jam kerja untuk pekerjaan struktur atasnya pada beberapa lantai saja dengan pembagian 8 zona tersebut.

B. Biaya pekerjaan bekisting

Tabel 12. Total Biaya Pekerjaan Bekisting

\begin{tabular}{ccccc}
\hline \multirow{2}{*}{ No. } & \multirow{2}{*}{ Jenis Bekisting } & \multicolumn{2}{c}{ Biaya } & \multirow{2}{*}{ Total Biaya } \\
\cline { 3 - 4 } & & Material & Tenaga Kerja & \\
\hline 1 & Konvensional & $\mathrm{Rp} \mathrm{4.224.942.727,00}$ & $\mathrm{Rp} \mathrm{2.761.424.007,00}$ & $\mathrm{Rp} \mathrm{6.986.366.734,00}$ \\
\hline 2 & Aluminium & $\mathrm{Rp} \mathrm{6.388.948.712,58}$ & $\mathrm{Rp} \mathrm{1.602.599.842,28}$ & $\mathrm{Rp} \mathrm{7.991.548.554,87}$ \\
\hline
\end{tabular}

Berdasarkan total biaya pekerjaan bekisting pada Tabel 13 tersebut, dibutuhkan biaya lebih besar untuk percepatan durasi proyek dengan penggunaan bekisting aluminium. Meskipun demikian, pengadaan material bekisting aluminium tersebut merupakan investasi bagi kontraktor yang secara rutin memegang proyek-proyek bangunan tinggi. Penggunaan bekisting aluminium dapat diulang sebanyak 200-250 kali pemakaian. Sedangkan pada proyek $\mathrm{X}$ bekisting hanya akan digunakan sebanyak 30 kali yaitu dari lantai 5-34 sehingga jika dari segi biaya bekisting 
aluminium dibandingkan dengan bekisting konvensional baru terpakai 2/3 biaya pengadaan materialnya dan dengan penyusutan yang kecil yaitu 3/25 kali pakainya atau 0.12 kali pakainya yang berarti penggunaan bekisting aluminium ini juga merupakan keuntungan bagi kontraktor karena dapat digunakan lagi untuk proyek-proyek lainnya.

Tabel 13. Tanggal Pelaksanaan Proyek dan Waktu Selesai Struktur Atas

\begin{tabular}{|c|c|c|c|c|c|c|}
\hline \multirow{3}{*}{$\begin{array}{l}\text { Tabel } \\
\text { Biaya }\end{array}$} & \multicolumn{6}{|c|}{ *Rencana: Durasi Proyek = 730 hari \& Waktu selesai struktur atas = Juli 2020} \\
\hline & \multirow{2}{*}{$\begin{array}{l}\text { Material } \\
\text { Bekisting }\end{array}$} & \multirow{2}{*}{$\begin{array}{l}\text { Jumlah } \\
\text { Zona }\end{array}$} & \multicolumn{2}{|c|}{ Tanggal Pelaksanaan } & \multirow{2}{*}{$\begin{array}{c}\text { Durasi } \\
\text { Proyek } \\
\text { (hari) }\end{array}$} & \multirow{2}{*}{$\begin{array}{l}\text { Waktu Selesai } \\
\text { Struktur Atas }\end{array}$} \\
\hline & & & Mulai & Selesai & & \\
\hline & \multirow{2}{*}{ Aluminium } & 6 & 19 Juli 2019 & 13 Agustus 2021 & 729 & September 2020 \\
\hline & & 8 & 19 Juli 2019 & 26 Juli 2021 & 711 & Agustus 2020 \\
\hline
\end{tabular}

Pekerjaan Bekisting Proyek X

\begin{tabular}{ccccc}
\hline \multirow{2}{*}{ No. } & \multirow{2}{*}{ Jenis Bekisting } & \multicolumn{2}{c}{ Biaya } & \multirow{2}{*}{ Total Biaya } \\
\cline { 3 - 4 } & & Material & Tenaga Kerja & \\
\hline 1 & Konvensional & Rp 4.224.942.727,00 & Rp 2.761.424.007,00 & Rp 6.986.366.734,00 \\
\hline 2 & Aluminium & Rp 6.388.948.712,58 & Rp 1.602.599.842,28 & Rp 7.991.548.554,87 \\
\hline
\end{tabular}

Tabel 15. Koefisien Tenaga Kerja Bekisting Alumnium

\begin{tabular}{ccccc}
\hline \multicolumn{5}{c}{ KOEFISIEN TENAGA KERJA } \\
\hline \multirow{4}{*}{ No. } & \multirow{2}{*}{ Elemen } & \multicolumn{3}{c}{ Koefisien } \\
\cline { 3 - 5 } & & Pekerja & Mandor & Tim bongkar \\
\hline 1 & Kolom & 0,1089 & 0,0545 & 0,0321 \\
\hline 2 & Balok & 0,2307 & 0,1154 & 0,0445 \\
\hline 3 & Dinding & 0,1089 & 0,0545 & 0,0321 \\
\hline 4 & Plat Lantai & 0,1144 & 0,0572 & 0,0426 \\
\hline
\end{tabular}

\section{Koefisien dan Biaya Tenaga Kerja Pekerjaan Bekisting Aluminium}

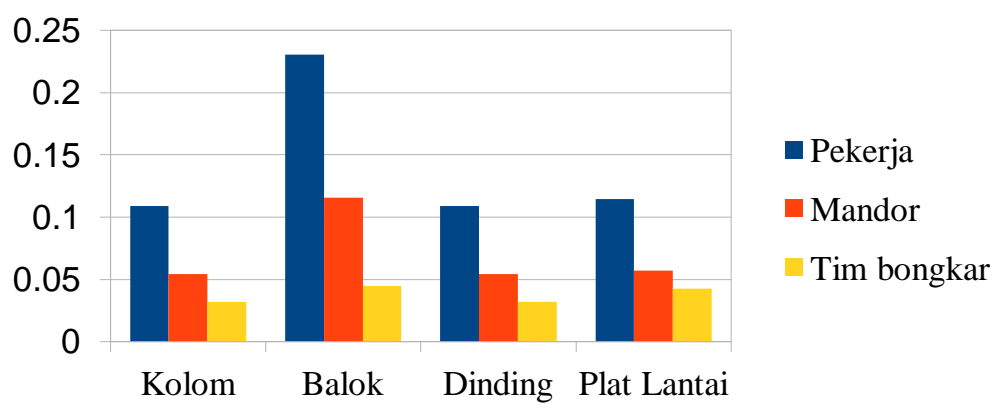

Gambar 3. Koefisien dan Biaya Tenaga Kerja Pekerjaan Bekisting Aluminium

\section{KESIMPULAN DAN SARAN}

\section{Kesimpulan}

Dari hasil perhitungan dan pembahasan dapat disimpulkan sebagai berikut: 
1. Dengan mengganti bekisting konvensional menjadi bekisting aluminum pada pekerjaan struktur atas untuk pembagian 6 zona diperkirakan bisa menyelesaikan proyek 16 hari lebih cepat, dan untuk pembagian 8 zona diperkirakan bisa menyelesaikan proyek 34 hari lebih cepat. Sedangkan untuk pekerjaan struktur atas belum dapat diselesaikan pada bulan Juli 2020. Tanggal pelaksanaan proyek dan waktu selesai pekerjaan struktur atas dapat dilihat pada tabel 14.

2. Dengan mengganti bekisting konvensional menjadi bekisting aluminum akan menambah beban biaya modal kontraktor dengan investasi bekisting aluminium sebesar Rp 6.388.948.713,00. Perbandingan biaya pekerjaan bekisting proyek X dapat dilihat pada tabel 15.

3. Bekisting aluminium merupakan investasi awal yang baik untuk kontraktor yang secara rutin memegang proyek-proyek bangunan tinggi karena berdasarkan penyedia bekisting, pemakaiannya bisa untuk 200250 kali pemakaian, sehingga jika sudah dipakai 30 kali pada proyek X masih dapat dipakai untuk proyek-proyek berikutnya.

4. Hasil perhitungan untuk nilai koefisien tenaga kerja pekerjaan bekisting aluminium dapat dilihat pada tabel 15. Sedangkan grafik koefisien tenaga kerja pekerjaan bekisting aluminium dan biaya tenaga kerja dapat dilihat pada gambar 3 .

\section{Saran}

Setelah dilakukan pembahasan pengaruh perubahan pemakaian jenis bekisting terhadap durasi dan biaya pelaksaanaan pekerjaan struktur atas proyek X, maka dapat disarankan hal-hal sebagai berikut:

1. Penambahan jumlah jam kerja untuk beberapa lantai pada pekerjaan struktur atas dengan pembagian 8 zona dengan harapan pekerjaan struktur dapat selesai pada bulan Juli 2020.

2. Merencanakan alternatif percepatan pada metode pekerjaan konstruksi selain pekerjaan bekisting.

3. Koefisien tenaga kerja yang didapatkan merupakan hasil perhitungan dan pengamtan dari 1 proyek, sehingga dapat dilakukan penelitian lebih lanjut dengan data yang lebih banyak agar didapat nilai koefisien tenaga kerja yang dapat mewakili secara statistic yang kemudian dapat dijadikan sebagai acuan perhitungan biaya koefisien tenaga kerja bekisting aluminium di Indonesia.

\section{DAFTAR PUSTAKA}

Barnes, Ralph M. (1980). Motion and Time Study design and Measurement of Work. Edisi VII. New York: Willey and Son,

Peraturan Menteri Pekerjaan Umum No. 11/PRT/M/2013 tentang Pedoman Analisis Harga Satuan Pekerjaan Bidang Pekerjaan Umum. (2013).

Project Management Institute. (2017). A guide to the Project Management Body of Knowledge (PMBOK guide) (6th ed.). Project Management Institute.

Soeharto, Iman. Manajemen Proyek (Dari Konseptual Sampai Operasional). (1999). Edisi Kedua. Jakarta: Erlangga.

Widiasanti, I. dan Lenggogeni. (2013). Manajemen Konstruksi. Bandung: PT. Remaja Rosdakarya.

Wigbout, F. (1992).Bekisting (Kotak Cetak). Jakarta: Erlangga.

Wignjosoebroto. (1995). Ergonomi Studi Gerak dan Waktu Teknik Analisis untuk Peningkatan Produktivitas Kerja. Surabaya: PT. Guna Widya. 